\title{
Why the Practice of Business Ethics Calls for a Due Regard for History $^{*}$
}

\section{FREDERICK BIRD ${ }^{* *}$}

In this essay I will examine four reasons why a due regard for history is important for business ethics. These are as follows: (1) In order to learn and to appreciate local cultural norms and practices; (2) In order to understand both how current problems developed as they have and how to envision the current responsibilities for past legacies; (3) In order to gain a lively sense of what is now possible and what is not and when what kinds of actions are called for; and (4) in order to monitor existing practices as they evolve over time.

Keywords: Ethics, History, Business, Contingencies, Responsibilities, Legacies

\section{Warum die Prax is der Unternehmensethik einen sorgfältigen Blick in die Geschichte braucht}

In diesem Essay werde ich vier Gründe untersuchen, warum ein sorgfältiger Blick in die Geschichte für Unternehmensethik wichtig ist: (1) um lokale kulturelle Normen und Praktiken schätzen zu lernen; (2) um zu verstehen, wie gegenwärtige Probleme entstanden sind und welche Verantwortung für die Vergangenheit besteht; (3) um einen lebhaften Sinn dafür zu entwickeln, was jetżt möglich ist und was nicht, und wann welche Art von Handlungen gefragt sind; und (4) um zu beobachten, wie bestehende Praktiken sich über die Zeit entwickelt haben.

Schlagwörter: Ethik, Geschichte, Unternehmen, Kontingen₹, Verantwortung, Vergangenheit

\section{Introduction}

Often we associate the practice of ethics with efforts to make judgments about how to act with respect to particular issues by invoking general, often universal normative standards - whether these are expressed in the form of principles, values, rights, rules, virtues, or ends. This is the approach to ethics modelled especially in the works of Plato, Aquinas, Kant, and Rawls, as well as in sacred texts like the Dhammapada, the Qur'an, Leviticus and Deuteronomy, and Canon Law. An equivalent approach is embodied in the efforts to arrive at common normative standards for business practices as these are set forth in business codes like the SA 8000, the ISO 14000, Benchmarks for Excellence,

\footnotetext{
* This paper is a revised version of the article "Why the Responsible Practice of Business Ethics Calls for a Due Regard for History" by Frederick Bird. It was originally published in the Journal of Business Ethics Vol. 89/No. 2 (2009), pp. 203-220, and was taken over with permission of Springer.

** Prof. Dr. em. Frederick Bird, Department of Political Science/University of Waterloo, 200 University Avenue West, Waterloo, ON, Canada, Tel.: +1-(0)519-8884567, E-Mail: fbird@uwaterloo.ca, Fields of Research: Business Ethics, Global Ethics, Global Poverty, Comparative Ethics, Ethics as a Social Practice.
} 
and guidelines used to grade businesses for the purpose of ethical investing. In this essay I will argue for an alternative - and, I think, complimentary - approach to ethics which takes history - and therefore, legacies of the past, current contingency, on-going developments, and the possibility of change - far more seriously. The standard approach to ethics is largely ahistorical. Basic ethical principles are set forth and invoked as if they were relevant for all time and all places. The alternative approach, which I will defend, recognizes that responsible ethical judgments must be informed as well by a due regard for history. ${ }^{1}$

The position I am defending is not new. Nor, as I will later demonstrate, is it relativistic, as this term is usually understood. This historical view of ethics has been expressed by a number of authors who have been especially interested in fostering responsible ethical judgments. These include Thucydides, as he reviewed the irresponsible judgments that led to and prolonged the Peloponnesian wars and Machiavelli, who in his Discourses reflected on both ancient Roman history and contemporary events in order to exercise practical moral judgments about the practice of politics (see Thucydides 1954; Machiavelli 1950/1532). Both Montesquieu and de Tocqueville adopted historical approaches to ethics, as they attempted to determine the prospects and problems connected with political reform. Both realized that one model did not fit all cases (see de Tocqueville 1945/1840). Recently both McIntyre in After Virtue (1981) and Jonsen and Toulmin in the Abuses of Casuistry (1988) have attempted to demonstrate why a due regard for history was important for the contemporary practice of ethics (see McIntyre 1981; 1988). Reviewing an alternative tradition of ethics associated, they argue, with Aristotle, Cicero, one reading of Aquinas, early modern casuists, and contemporary medical ethics, Jonsen and Toulmin, championed a case based approach to ethics that takes seriously how historical circumstance shaped the understanding and possibilities for addressing particular ethical issues (Jonsen/Toulmin 1988).

Weber famously contrasted these two approaches to ethics broadly in his essay "Politics as Vocation". He distinguished between what he referred to as an ethics of absolute ends and an ethics of responsibility. The former held certain norms, values, and ends in absolute terms. He regarded the Sermon on the Mount as an example of this ethic. He might well have added Kantian ethics or efforts taking place in the era that he wrote to establish rules of war by means of the Geneva Conventions. He associated the ethics of responsibility with practical ethical efforts to arrive at pragmatic judgments that sought to balance means, ends, and secondary consequences in response to historical exigencies (see Weber 1946: chap. 2). Influenced either directly or indirectly by Weber and his colleague Ernst Troeltsch, a number of contemporary Christian ethicists, such as both Reinhold Niebuhr (1942) and his brother H. Richard Niebuhr (1963), have variously attempted to set forth an ethics of responsibility that called for moral actors to be especially attentive and responsive to current historical problems and possibilities. ${ }^{2}$

1 In this essay I will especially focus on the practice of business ethics but the concerns I raise and the positions I take are relevant for the practice of ethics generally.

2 A number of other ethicists especially influenced by a due regard for history could be added to this list including especially Marx, in German Ideology (1947/1932), The Eighteenth Brumaire 
I use the phrase "practice of ethics" to refer to a range of activities including exercising judgment, evaluating actions, mobilizing people and resources to realize objectives, and acting deliberately in so far as those involved are guided in the process by normative notions of obligation, responsibility, and value. Many ways of approaching decisionmaking are not ethical. We act a-ethically, for example, whenever we are moved to make decisions on the basis of inclination (that is, by virtue of personal taste) or because we are coerced. Our decision-making remains non-ethical as well in so far as we act simply tactically, in order to maximize objectives at lowest costs or in so far as we act out of unreflective habit (see Habermas 1981: Interlude). Alternatively, we act ethically in so far as we determine how we ought to act by making reference to various normative notions with respect to goals, ways of acting, conventions, and motivations and intentions. Often these normative notions have been well articulated in legal, philosophical, religious, ethnic, professional, and political terms. The practices of ethics involves the everyday utilizations of these notions as we make decisions and assume responsibility for the decisions we make and expect others to do likewise. If the callings of science and politics are typically restricted to those engaged in various ways in the practice of science and politics, the calling of ethics is the unavoidable vocation for all humans in so far as we take responsibility for our own lives.

In keeping with this tradition of historically-minded ethicists, in this essay I will begin by spelling out a number of reasons why a due regard for history is vital for the practice of ethics generally, and for business ethics in particular. In part this essay serves as an explanation and apologia for the approach to business ethics adopted for the research project I directed on "Justice and the Practices of International Businesses in Developing Areas" and for the format we have used to describe the findings of this project in special issues of the Journal of Business Ethics as well as in three books published by Palgrave-Macmillan (2004; 2005; 2006). In all cases we have situated our case studies of particular firms within historical accounts of the developing areas in question. In order to render responsible judgments of the practices of these firms, we have argued that it was necessary first to gain an educated sense of the historical context in which they found themselves (see Bird/Herman 2004; Bird et al. 2005; Bird/Velasquez 2006, and Bird/Smucker 2007). In this essay I use the phrase "a due regard for history" to point to a number of inter-related assumptions, attitudes, and ways of looking at the world. These include the following: a respect for the ways past experiences shape present realities; an appreciative recognition that we can learn much that is useful by considering how people have dealt with challenges in the past; a deep acknowledgment of the ways things keep changing; a solid appreciation for contingency - how opportunities and threats are associated with the ways particular events unfold; and, finally, a recognition that in a number of different ways time matters - not only does it take different amounts of time to realize various objectives but also that there is a timeliness that needs to be taken into account as we determine how to act.

(1971/1851) and the sections of his Grundrisse (1973/1939) surveying pre-capitalist economic formations. 


\section{The Practice of Ethics and Respect for Historical Conventions}

As we began our studies of international businesses in developing areas, we quickly saw that diverse cultural mores deeply influenced moral attitudes in the countries in which we were undertaking research. The customary moral expectations of Vietnamese, for example, differed not only from the foreign firms investing there but also from customary norms in other countries where we were conducting research like South Korea, Ghana, Guyana, and Colombia. Attitudes toward women in the labor force differed so that what might be acceptable in Uganda would not be acceptable in Pakistan. From country to country there were differences with respect to the norms guiding bargaining practices, attitudes towards work, ways of managing laborers, as well as questionable payments.

Several consequences follow from this recognition that people in these varied countries are influenced by their own culturally embedded normative expectations. To begin with, it is important to respect the fact that as people engage in modern business practices like working, selling, managing, and negotiating, they are already influenced by moral expectations, as these have been communicated by word of mouth, oft-told stories, local etiquettes, mores, and customs. These are historically shaped conventions - implicitly agreed-upon ways of acting. In so far as they are regarded as valued and/or obligatory ways of acting, these conventions are normative (see Durkheim 1974/1925). If one of the aims of ethics is to influence how people ought to act, then we are welladvised to begin by appreciating the ways they already feel they ought to act as guided by the mores by which they live. It is also important to recognize as well that these mores may be quite influential even in settings where they are taken for granted like common sense and not overtly articulated (see Sumner 1906; Taylor 2004). For example, in his book Moral Mazes, Jackall demonstrated the ways managers of the businesses he studied were deeply influenced by implicit moral assumptions - what he referred to as ethics-in-practice - associated with a professional interest in their own careers and loyal support for the positions adopted by their superiors. These moral values were far more likely to shape behaviors than the explicit moral codes these managers overtly endorsed (see Jackall 1988). It is far easier to convince people to adopt new standards by building upon, and sometimes modifying or extending, normative expectations shaped by their own mores. A due regard for history then encourages us to find ways of connecting our own moral agendas to the traditions which have shaped the moral agendas of the diverse people we encounter. ${ }^{3}$ The same might be said of countries as different as Iran and India, Brazil and Guyana, Vietnam and Pakistan.

It is helpful to understand diverse cultures in relation to the images and stories people embedded in these cultures use to express their values, to guide their decisions, and to justify their actions. This point may seem obvious but it is often ignored or violated in practice. There have been a number of studies that have attempted to characterize cultural differences by utilizing standardized measures, to gauge the degree to which people

3 In our initial studies in business ethics, Jim Waters and I first attempted to gain a lively sense of moral issues from the perspective of managers before we began to recommend how they ought to address the ethical issues they faced (see Waters/Bird 1987; Waters et al. 1986, Bird/Waters 1986, and Bird et al. 1990). 
in particular cultures were, for example, more individualistic or collectivistic, more oriented to the past, the present, or the future, more likely to assign worth in terms of achievements or status, and/or more likely to value equality or liberty. Studies undertaken by Kluckholm and Strodbeck (1961), by Rokeach (1979), and by Hofstede (1980; 1991) have been widely cited and frequently used as points of reference for understanding cultural differences. While these studies have underlined the diversity of cultures and provided analytical terms of reference, these analytical terms are not for the most part the terms by which people in diverse cultures understand themselves. ${ }^{4}$ The latter are much more likely to draw upon events in their own histories, which especially illumine and characterize the norms and values of their mores. As they determine how to act, business people from Malaysia, Indonesia, China, South Africa and Fiji characteristically cite precedents from their own traditions and experiences. If we hope to understand the ethical perspectives of these people, we need to develop a due appreciation for their traditions and the normative stories and precedents they cite. ${ }^{5}$

In order to understand the particular crises they are now facing and the moral orientations through which current events are understood in Fiji or Malaysia, for example, it is necessary to know and understand their histories. The present conflicts in Fiji are prefigured in events of the late nineteenth century which led the British as colonial masters in Fiji to ship thousands of South Asians to Fiji to help harvest the lucrative sugar cane crops. However, because of native Fijians sense of connection with their land, the South Asians who came to work on and farm these lands were given extended lease without

$4 \quad$ It makes considerable difference for methodological reasons whether these typological scales are treated as classificatory schemes as used in biology or chemistry or analytical schemes - heuristic indicators - as proposed by a number of social scientists, including especially Weber in his account of ideal types (see Weber 1949/1904). To be sure, many social scientists in practice treat their typologies as either/or classificatory taxonomies.

5 From an historical perspective, moral conventions refer to human efforts to realize in practice normative ideas, whether these are viewed as standards, virtues, sentiments or objectives. People do not simply have ethical commitments. Rather, they have ethical convictions, habits, and sentiments, which they variously seek to practice over time in the face of not only opposition, resistance, and alternative moral positions, but also unanticipated contingencies, varied distractions, boredom, and forgetfulness. Correspondingly, whenever we attempt to identify the ethics of any other, whether person or group, we are called upon to examine both the communicative expressions of these moral convictions and commitments as well as actual behaviors as people act to put these ideas into practice. Behaviorists typically assume that it is sufficient to review and focus on conduct and practices because, they argue, verbal expressions of ethics that are not acted upon do not matter (see Scott 1971). Alternatively, idealists propose that we identify any one's ethics with the norms, virtues, conventions, and values they profess and seek to realize. Both behaviorists and idealists focus on part of the larger dialectic reality of ethics. The latter involves the ongoing moral tension between convictions and experiences, between sentiments which assume the form of aspirations and/or obligations and actual practices, between what we are seeking to become or to realize and what we are actually able to accomplish. To be sure, neither psychopaths nor hypocrites experience this tension. However, all other humans do, at least to the extent that they either directly seek to act in keeping with normative expectations or they make efforts to articulate good reasons why not. When we examine moral conventions historically, we then are reminded to pay attention to the ways over time, people not only shift their convictions in light of their experiences but also variously change their practices in light of the ways they regard their convictions. 
the right to actual ownership. Today the population sizes of the Fijians who originally came from South Asian and the Fijians who are indigenous are about the same. However, the two groups possess quite different attitudes towards the land of Fiji that cannot be easily reconciled. There have been equivalently strong cultural conflicts in Malaysia between the indigenous Malays, who are largely Muslim, a population of Chinese (about 30 percent) who have immigrated there over a number of centuries, and a population of South Asians (about 8 percent) who migrated there in nineteenth century. However, Malaysia's history has been different. There were no restrictive land codes. There were, nonetheless, a number of violent civil conflicts, reaching a climax in the late fifties. At that time the government instituted a number of affirmative action initiatives. As a result, cultural differences continue but they have been affected both by the history of overt conflicts and public efforts to mediate them.

When we adopt an historical perspective with respect to cultures and cultural differences, we are led to recognize that cultures are not static. They change over time. For example, the current "traditional" culture of Nunavik Inuit in Northern Quebec developed as a result of the centuries of contacts between these people and the French and British fur traders. Before these Europeans arrived, Inuit culture was not measurably influenced by this trade. The contemporary Inuit culture has been deeply affected recently by changes that led these people over the course of the twentieth century to move into settled villages. Cultures evolve. The anthropologist Sharon Hutchinson has provided an impressive account of the way the culture of the Nuer, classically studied by Evans-Pritchard in the 1930's has changed over the course of the twentieth century in response to modern economic and political forces in Sudan (see Hutchinson 1996). Many of the assumptions recorded by Evans-Pritchard are no longer valid. When we fail to view cultures historically, we are likely to overlook significant developments in the mores and normative expectations within particular peoples. A significant example of such changes can be found among the Afrikaner people of South Africa. Originally they had developed ideas about "apartheid" because as a people who had fled religious persecution in Europe and political oppression at the hands of the British colonists in the Cape Province, they had sought to maintain their values by separating themselves apart from other European peoples (see Hexham 1981). These attitudes led to and reinforced their views for keeping the Black population separated from the European colonists and their descendants as much as possible in their own lands or rather the lands to which the latter were assigned. Apartheid ideas then came to justify, not primarily their own sectarian communalism, as these ideas were originally developed, but rather violent systems of discrimination, regimentation, and oppression against Africans. While many Afrikaners vigorously defended this hardened police-state system of apartheid as it had become, many others began to question its current expressions and looked, often to be sure reluctantly, for new ways of preserving their culture within the pluralistic society that South Africa had become by virtue of its history. The culture of the Afrikaners has in the process evolved.

It is useful to look historically at the current interest in corporate social responsibility. This is not a new interest on the part of business people. For more than a century business people, business organizations, and critics of business have talked about and implemented programs designed to embody and to foster socially responsible business 
practices. Over the years the particular focus and character of this interest have changed (see Smucker 2006). The recent interest, for example, has in part been occasioned by political changes by which governments have both limited their regulatory role with respect to the social impact of businesses and limited as well their direct funding of social programs. The contemporary interest in the social responsibility of businesses thus has emerged at the same time as there has been a marked increase in the numbers and social involvements of civil society organizations, many of which have sought private sector support in the form of voluntary engagements, financial donations, sponsorships, and partnerships (see Sagawa/Segal 2000).

\section{Historical Roots of Contemporary Ethical Challenges}

Often we can best understand current problems and dilemmas by gaining a due appreciation of the way these situations came to be. For example, as we attempt to understand the contemporary debt crises in developing countries, it is useful to see how these financial problems arose. From the perspective of developing countries, their financial prospects were dramatically exacerbated in the early eighties by marked and adverse changes in the exchange rates offered by the United States to developing countries occasioned in turn as the US became a capital importer to meet its massive public debts. These debts in turn grew out of the Vietnam War expenditures, increased military spending, and the Oil crises in the early 70's and early 80's (see Milanovic 2005: chap. 7). Similarly, it is useful, as we seek to understand the current crisis in Fiji, to review the history of inter-group relations there between the indigenous Fijians and those descendants of ancestors who moved to this country at the end of the nineteenth and beginning of the twentieth century. Likewise, one can gain a fuller understanding of contemporary debates over the forms and utility of aid programs, voiced, for example, by analysts like Jeffrey Sachs and William Easterly, by looking over the varied aid programs over the past fifty years and their quite mixed results (see Sachs 2005; Easterly 2006).

An historical approach toward the ethical challenges facing international businesses in developing countries inevitably calls us to consider legacy issues. Legacy issues represent a special grouping of contemporary issues which have been shaped usually in negative ways by actions taken by particular agents in the past. It is useful to cite several examples before undertaking a fuller discussion of this topic. There is a current debate, for instance, over whether and to what degree Texaco might be held responsible for present environmental damages and human illnesses, which may have been caused directly and indirectly by Texaco's operations in eastern Ecuador fifteen years ago, before Texaco sold its operation there (see Business \& Human Rights Resource Centre 2016). To cite another case, a number of observers have argued that current problems faced by countries like the Congo, Angola, Zimbabwe, and Equatorial Guinea are derivative in part of the ways the previous colonial regimes exploited resources, distributed land titles, and/or failed to develop adequate transitional systems of public administration. Correspondingly, it has been asserted that the current governments of Belgium, Portugal, the United Kingdom, and Spain might well be obliged to offer special assistance to these countries (see Klitgaard 1990). It might well be argued that the mining firm Freeport Indonesia ought to take steps now to deal with the considerable environmental damage in Indonesia caused by their mining operations in that country during the seventies and eighties. 
How should we think about these kinds of legacy issues? To what extent are people in the present responsible for what their predecessors and ancestors did in the past? When as historians we recognize how certain past actions by identifiable agents have left debilitating legacies in the present, then, from the perspective of ethics, what kinds of normative judgments seem fitting with respect to the accountability and responsibility of either the actual descendants of - or the organizations that serve as the current institutional settings for - those former agents? This is not an easily answered question. To begin to think about an answer, we are called to acknowledge that historical changes matter. It is often impossible to undo what has been done years and decades before. Hopefully, we can learn from past mistakes, if and when we are honest enough to admit them. As well we can learn from past accomplishments. However, this kind of learning does not address questions of contemporary accountability for the present legacy of past actions.

One strategy for dealing with legacy problems is to think about them in terms of models of compensatory justice. These models, for example, have been used successfully to sue cigarette companies for harm to the health of their customers. In this case it has been argued that even though these firms complied with current laws and their customers made their own voluntary choices to buy and smoke cigarettes, the firms were aware of harmful features of their products, which they failed to communicate clearly to these customers. Compensatory models have likewise been used against companies that have knowingly polluted streams or sold unsafe products. However, compensatory models are not as well suited for thinking about adverse legacy problems occasioned by firms that complied with current legal and social standards and did not cover up relevant adverse information. In these cases, it might well be asked, should contemporary descendants be held accountable to compensate those injured by past practices just because the legal and conventional standards were lower or inadequate in the past? Many would argue that it seems unfair to hold people in the present liable for penalties because of what their ancestors or predecessors did. ${ }^{6}$

The compensatory justice model becomes more compelling, however, when the focus shifts from identifying culpable individuals to finding culpable organizations. In some cases it would seem appropriate to hold accountable not individuals but the present embodiment of on-going organizations which initially occasioned this harm through, for example, willful negligence or the failure to exercise due diligence. Accountability would seem to be fittingly assigned to these organizations especially in settings where it could be demonstrated that current descendants of those originally harmed have as a result suffered corresponding losses. Accordingly, these organizations could now be held responsible not because they have benefited but because in the past they willfully acted in ways that resulted in harm that could have been limited or avoided if these organizations had acted differently in ways that can be demonstrated to be economically feasible and practically possible. By failing to explore these alternatives - especially in settings where equivalent firms have indeed acted to reduce adverse effects - it could be argued that these firms were correspondingly not exercising due diligence. In the present, therefore, these firms might then be fittingly held accountable and could be called upon to compensate those who now suffer deprivations as a result of the legacy of past practices. If it can be demonstrated that in the recent past firms were negligent or failed to exercise due diligence and that they thereby allowed serious harm to be done so that the current generation is now adversely affected, as a result, for example, by mining operations, tax avoidance policies, or unhealthy working conditions, then it would seem just that firms in question could be called upon to compensate those currently disadvantaged. 
Alternatively, legacy issues can be framed in terms of arguments about re-distributive justice. Just as it has been argued that those who have more wealth - as a result of various historical developments as well as their own efforts - should pay progressively higher taxes, it might be argued that firms which have benefited from past operations should be ready to offer proportionately more services, taxes, philanthropy, and/or royalties to benefit those groups that have been adversely affected by these same developments. As some have benefited from industrialization in South Africa, China, Malaysia, Fiji, and Indonesia, others have been ill affected. Are those who have benefited and their descendants in some ways obligated to help those who have been injured and their descendants? To answer affirmatively assumes that those who have especially benefited from historical developments in excess of their own efforts are obliged to offer assistance to help those who have been disadvantaged, to the extent that the distresses of the latter are at least in part traceable to historical developments they were not in position to alter. Or, to state this argument in more neutral terms, can public authorities appropriately raise the rate of taxes on those who have especially benefited in order to provide fitting services to those who have been disproportionately disadvantaged? Basically, this position either calls for those who have especially benefited to help others from their superfluity or for the governments to raise the rate of taxes on the wealthy in order to provide benefits for the poor. This position does not assume that those who have benefited are culpable for the misery of the disadvantaged. Hence, this is an argument with respect to re-distributive justice and the common good not about just compensation.

From the perspective of developing areas, it must be acknowledged that it is easier to construct ethically credible arguments for compensation in these kinds of cases than it would be to lodge legally compelling complaints. The difficulties in doing so are multiple and severe. Many countries do not possess the laws or courts to hear and adjudicate these complaints fully and appropriately. Many of those affected lack the resources to represent their interests adequately. Furthermore, even when these institutions and resources are available, it would be difficult in many cases to establish in legally credible terms relevant examples of negligence or lack of due diligence. ${ }^{7}$

There is, however, another way of framing legacy arguments: namely, in terms of distributive justice and the common good rather than in relation either to models of compensatory justice or to models of re-distributive justice. Legacy arguments instead can be framed in terms of how past actions affect present distribution of opportunities and opportunity costs. Attention focuses on how current opportunities are structured. In

\footnotetext{
I can illustrate this problem with an example. Barama Forestry contracted with the Guyanese government to $\log$ in the Northwest region of that country, an area populated by several indigenous peoples. The firm logged targeted areas largely in keeping with the environmental standards of the Forestry Stewardship Council. However, it made no significant efforts to collaborate with authorities among the local indigenous peoples, to recognize and protect their traditional property rights, and to protect these areas from access by non indigenous wildcat miners. As the firm was leaving, these miners used the logging roads to enter the area and begin looking for gold in local streambeds. These same artisanal miners abused the indigenous villagers, especially the adolescent girls. They caused considerable social and physical harm to the villages. Barama might easily have taken a number of steps to protect these villages, such as rendering the logging roads impassable after they had been used. Because of the way these events unfolded, it is now very difficult for the indigenous to seek recompense for the harm done (see Whiteman 2004).
} 
particular, we are called upon to inquire whether some groups may face especially difficult conditions in their efforts to lead the kinds of lives they would like to live or to improve upon their lives because of ways their present circumstances have been adversely affected by past actions - such as, for example, the pollution of the streams or ground water, seizure of much of their traditional lands, or a history of un- and underemployment. Rawls has argued that we are justified in introducing inequalities in various social rewards and benefits only in so far as the allowance for these inequalities in turn occasions developments by which the circumstances of the least advantaged groups are improved (see Rawls 1970: chap. 2). In the name of justice and equal liberty, we are called upon to reduce and eliminate discrimination. But, as Rawls has argued, a fair equality of opportunity means recognizing when the opportunities of some groups have been compromised by past actions and then taking appropriate actions in the present to enhance their opportunities. Accordingly, Malaysia introduced affirmative action policies in the 1970's precisely in order to augment the opportunity structures for groups that had suffered from discrimination in the past.

A due regard for history profoundly affects the way we make ethical judgments. Historical developments present different kinds of challenges both at different times and in different places. Among these challenges are various legacies from the past that cannot be ignored. Many groups have, sometimes quite appropriately and quite successfully, adopted a backward looking view of history to demand compensation for wrongs. However, it is also possible and sometimes fitting, to adopt a forward-looking appreciation of history and correspondingly to manage these legacy problems by fostering the current opportunities of those adversely affected.

\section{Reviewing History to Determine Present Possibilities}

A due regard for history helps people discern what is and is not possible in the present both with respect to economic development and ethical initiatives. The range of opportunities in the present is deeply affected by what has already taken place. As we come to appreciate the way past events have shaped current circumstances, we thereby gain fuller, more sophisticated assessments both of where changes are more likely to occur (and not occur) and what character they are likely to take. To have developed an historically educated sense of current possibilities is a different stance than simply seeking to mine the past for action plans for the present. The latter attitude is well-exemplified by attempts to identify and copy the best practices of exemplary predecessors. This approach is imitative. It seeks directly to apply information we have received regarding previous experiences. In contrast, when we seek to cultivate an educated historical sensitivity, we aim at fostering not only a greater sensitivity to changing circumstances and practical wisdom informed by learning from predecessors, but also an appreciation how we can learn from missed opportunities, mistakes, as well as successful actions. These contrasting attitudes towards historical examples are well illustrated by the different positions Machiavelli adopted in his The Prince (1950/1532) and The Discourses (1950/1531). In the former he didactically invokes historical examples to call for a strong leader who might act in the present to unify the Italian city states. In the latter, Machiavelli reviews a wide range of complex examples, both from the history of ancient Rome and contemporary history, to reflect on a number of possible lessons and corresponding policy guidelines. 
A due regard for history can correspondingly educate our sense of possibility in several ways. One, a due regard for history helps to acquaint us with the specific forms of local predicaments and prospects. Marx once famously wrote that humans can act to shape the course of history. However, he added that they cannot proceed just as they might please. Rather, they can only move forward in relation to the particular conditions determined by the past (see Marx 1861/1851: 15). We can illustrate this point by referring to a number of examples. For instance, with the exception of several periods of civil strife, China has been governed by a centralized, patrimonial state administration for over two millennia. Hence, one would suspect that any efforts to introduce democratic political processes in China will, to the extent that they are successful, emerge in ways that modify but do not directly undercut these inherited patterns of public authority. These changes may, for example, assume the forms of fostering democratic processes at village and municipal levels, gaining a modest autonomy for courts, requiring greater public accountability of public officials, and/or by proliferation of diverse civil society organizations (see Thorton 2008). Or to refer to other aspects of the situation in China, given the fact that China has for centuries fostered innumerable technological inventions, which Joseph Needham has reported on in a number of books, it is also not surprising to see the extent that China has welcomed technological innovations during the past several decades. Current developments seem to be in continuity with past developments. To cite a different case, current efforts of South Africa to reduce unemployment and poverty are limited by the slow pace of investment in post-apartheid South Africa. The way forward seems to be conditioned by past developments. During the last years of the old system, even while they welcomed the political benefits of divestment, the leaders of the African National Congress foresaw the need to encourage new investment if South Africa was to be able to find sufficient levels of employment for its growing population. The apartheid system itself left of heritage abuse, distrust, and exploitation in the workplace and beyond that has not been easy to overcome. To cite a further example, the history of Fiji plays a major role in determining the prospects for economic development there. This history has shaped how both native and Indo-Fijians view their land and each other. Any constructive way forward will have to begin by respecting these factors.

The current social responsibilities of international businesses in these and other developing countries are directly shaped by their historical circumstances. What they ought to do is influenced both by what has come to be and by what they can effectively accomplish. They can and ought to make a difference by addressing current predicaments and aligning themselves with constructive developments in so far as they can do so as part of their regular business operations. In China international businesses can, for example, add significant economic value and foster progressive social developments by pursuing what Santoro has described as market building rather than cost minimization strategies. In the process, businesses pursuing these kinds of strategies, like Hewlett Packard, variously transfer technological know-how, support meritocratic human resource policies, and encourage individual initiative (see Santoro 2000). Given the history of South Africa, the special challenge that businesses in that country face is to find ways of attracting investments, creating employment opportunities, and integrating blacks into sectors of the economy and labor market previously dominated by whites. These are not small tasks given the extremely high rates of unemployment in the country. 
Two, a due regard for history fosters an informed sense of contingency and timing: of what is possible now, what is not, and what might be possible later. Many morally mandated changes not only require considerable time to put into practice. They are also more likely to be implemented when prior preconditions have been instituted. Sometimes, important changes have to wait until these preconditioning factors are ready. To cite a well-known example, in 1968 protestors in Prague realized, after Soviet tanks entered their city, that they would have to delay their hoped-for democratic revolution until times were ready, as they were twenty years later. Consider the issue of child labor. Clearly the reduction of abusive child labor has high priority. As we attempt to address child labor issues in the present, we can learn much from how the extent of child labor has been reduced in the past. Although there were many protests about child labor during the early years of industrialization in the North Atlantic countries, it was not these protest movements which played the largest role in reducing the numbers of child laborers. As industrialization proceeded, the extent of child labor everywhere declined. Two factors especially made a difference: namely, one, increases in minimum wage levels and increases in public spending for elementary and high school education. These factors worked to raise household incomes and render educational systems worthwhile in practice (see Basu 1999; Moehling 1999; Smelser 1959). Those who seriously seek to reduce child labor in developing countries today can well learn from thoughtful review of the history of industrialization in Europe and North America. They can campaign to raise minimum wage levels and increase investments in public education, in the process helping to create the preconditions that result in lower levels of child labor. Efforts to eliminate child labor through legislation and consumer boycotts have in many settings been either ineffective or produced unanticipated and unwelcome consequences. That is, the supposedly successful campaign against child labor used in the production of particular products, such as, for example, the soccer ball stitching in Pakistan, have occasioned reduced family income levels for former stitchers and the transfer of a number of the targeted children to seek employment in more dangerous and risky work situations (see Akabayashi/Psacharopoulus 1999; Bessell 1999; Khan 2007).

In these kinds of settings, a due regard for history fosters sophisticated strategic thinking with respect to the timing and direction of actions to produce relevant ethical outcomes. Strategic questions of timing are relevant to recent debates regarding the role of firms like Yahoo, Google, and Microsoft with respect to censorship laws in China. As a condition for operating within China, the government has required these firms to remove a number of terms and references - words like "human rights" and "democracy" and terms like "Tiananmen Square" - which cannot be accessed by ordinary internet users in China. By complying with these strictures, these firms de facto seem to have put themselves in the position of endorsing Chinese censorship. This compliance seems to be in flagrant violation of basic human rights. From an ethical perspective what then should these firms do? Viewed a-historically and a-strategically, it has been argued that these firms should withdraw from China. However, from a strategic and historical perspective, it is possible to view these issues as ones that can be and probably will be addressed gradually over time. It is possible to observe the way that internet use itself over time has tended to overcome or neutralize previous politically determined barriers 
to communication. In modest ways internet use has also allowed dissidents to communicate. Internet users have found ways to communicate around censorship rules. Even within these rules, the internet has fostered a great expansion in the degree to which Chinese citizens can raise concerns about public issues. Moreover, some Chinese continue to be able to access non-Chinese internet service. The internet services provided by Google, Yahoo, and Microsoft thus occasion developments that allow for more open communication by more people in spite of their tactical agreements to comply with current Chinese regulations for the time being. In the process, these firms may well be helping to put into place preconditions that will foster and protect extensions of the right to freedom of expression (see le Menestral et al. 2002).

When and how firms respond to social issues is not simply a matter of whether the issues in questions are important. It depends also on the relative capacity of firms to act effectively on particular issues at any point in time. This capacity in turn is influenced both by the firms' own (and also historically changing) ability to make a difference that is, to mobilize resources to produce significant outputs - and by the ways on-going historical changes have worked to establish relevant preconditions in the external situations they are addressing (see Dutton/Duncan 1987; Dutton/Ottensmeyer 1987). By adopting an historical perspective, firms are correspondingly better positioned to assess their changing capacity to mobilize their own resources to address various kinds of social issues. They are likewise better positioned to discern to what degree at present they can effectively make a difference with respect to the issues at hand.

Three, regarding the economic development, a due regard for history leads us to recognize certain broad patterns in the ways human communities have developed. In the broadest sense, humans have over time discovered ways to utilize natural and human resources more effectively. Through a series of innovations, which have been technological, organizational, and cultural, humans have found ways to produce more benefits and more wealth. By developing their own skills, by utilizing new and more powerful forms of energy, and by re-organizing their patterns of work, humans have learned ways to produce more and to raise their standards of living. ${ }^{8}$ In broad terms, it is possible to note the difference between societies that are highly developed in economic terms, the ones that are moderately developed, and the ones that remain undeveloped. What is possible in the present in terms of economic growth for any society is conditioned by the extent to which that society has already passed through various phases or stages of economic development. Thus, for example, industrialization is much more likely to occur in a society with developed agriculture and commerce than in a society characterized by a hunting and gathering economy.

Articulated in these kinds of broad terms, most observers would agree with these statements. Much controversy, however, surrounds questions about fitting ways to measure economic development and whether it is possible to identify any pattern in the ways the

In a number of areas (and at different times), these increases have, to be sure, resulted in the depletion and degradation of natural and human resources - as a result, for example, of pollution and unhealthy working conditions. In these settings real economic development has not really taken place. Reported increases in living standards represent a chimera, a misleading appearance, since it is not a productive use of natural and human resources to abuse them or run them down. 
economies of societies move from being undeveloped to more fully developed. ${ }^{9}$ To be sure, it makes sense in many ways to measure development, as Sen has argued, in terms of the degree to which humans are able to live the kinds of lives they are likely to value (see Sen 1999). However, in relative terms, this perspective, which gauges economic development in terms of outcomes enjoyed by individuals, fails to take account of technological and social arrangements of production that make these outcomes more or less likely. Alternatively, I think it is useful to inquire about those kinds of social and technological changes that in cumulative ways have not only resulted in producing more economic benefits - more goods, services, and wealth - from given human and natural resources but have also laid the foundations for further developments as well. One must be cautious in attempting to identify these critical changes. Liberal, Social Darwinist, and Marxist models of economic development have, for example, been widely criticized for imposing naïve, mechanical, ethnocentric, and progressivistic assumptions on their readings of history. Economies have developed in a much wider variety of ways than allowed either by Rostow's model of "Stages of Growth" or Marx's view of "Historical Materialism" (see Rostow 1960; Marx 1973/1939; Marx/Engels 1947/1932). Still, in broad terms, it is possible to discern patterns in economic development associated with a variety of technological, institutional, and infrastructural changes. For example, agricultural economies, which include the domestication of plants and animals, the introduction of irrigation, the development of transportation networks, and the institution of new patterns of property (private, cooperative, and collective), have been much more productive than hunting and gathering economies. ${ }^{10}$ Once societies have introduced and developed agriculture, then it is possible over time to introduce other changes in their economies associated, for example, with manufacturing and commerce. The point is that certain changes in culture, technology, and institutional arrangements have laid the foundations for subsequent changes.

Many of the accounts of economic development describe the process of development in abstract terms in relation to the realization of terminal values such as the enhancement of human capabilities, improvements in productivity, and increases in income levels. Alternatively, a due regard for history leads us to appreciate that this process of development takes considerable time and passes through multiple intermediate phases.

Most observers would agree that this development cannot adequately be gauged in relation to average per capita income because such a measure fails to account for wide variations within societies, fails to identify whether the economy in question is in fact making more productive use of human and natural resources, and fails to inquire about the degree to which higher income levels allow people to gain the primary goods - such as consumer goods and services, education, health care, political participation, cultural life - people are likely to want. Many would argue that development ought to be gauged in relationship to this latter category, namely the capability of people to realize these kinds of primary goods. The United Nations Human Development Index is based on a combination of such measures, which include life expectancy levels, literacy levels, infant mortality rates as well as income levels. These measures have merit but still do not indicate what economic factors especially work to help economies to operate so that humans can gain the capabilities to realize these primary goods. To identify and gauge the latter, we need some way of measuring how particular economies are making more effective use of natural and human resources so that people can develop these capabilities.

10 As Hugh Brody argues, agricultural societies have also introduced dis-economies as well (see Brody 2000). 
Moreover, many subsequent economic developments presuppose and have built upon previous developments, including especially the introduction and further growth of agriculture, local commerce, manufacturing, and the institutional changes and skill developments that make these changes possible. Correspondingly, we can then in proximate terms identify how developed any particular economy is in relation to a scaled range of possibilities, as economies institute various new forms of production and exchange as well new social, physical, and economic infrastructures. In a recent work, Sachs uses the phrase ladder of development to describe the relative situation of diverse countries. He points to countries which, like Malawi, have not yet gotten to the first rung on this ladder, other countries which, like Bangladesh, have made it to the initial rungs, other countries which, like Ghana, have progressed a bit further, and still other countries which, like Malaysia, have made significant progress (see Sachs 2005). The overall attempt to identify phases in development makes sense. However, the metaphor of a single ladder seems inappropriately to suggest that the overall pattern can be charted in relation to a single, linear model. The metaphor of a ladder becomes more adequate if we think of development in relation to multiple ladders, which reconfigure over times. In any case, viewing development in relation to multiple, cumulative phases, provides a useful point of reference for thinking about the specific limitations, possibilities, and strategies that seem relevant for any particular economy in the present.

Several consequences for the practice of ethics follow from adopting this kind of historical perspective with regard to development.

1. It makes sense when considering alternative policies with respect to development - take, for example, on-going debates regarding aid programs, tariff regimes, and investment strategies - to review the historical accounts of how industrialized countries have developed in the past. In sharp contrast to the current neo-liberal economic orthodoxies, most countries which have successfully industrialized - whether in the nineteenth century, the early twentieth centuries, or in the post world war era until the mid seventies - have benefited from selective tariff protection and significant government support for particular industries. Ignoring this history, neo-liberal economists have proposed alternative policies - such as an emphasis on liberalized markets and reduced government involvement in the economies of developing countries - which have resulted in significantly lower rates of economic growth in developing countries since the early eighties when these policies became dominant (see Chang 2007).

2. An historical perspective on development also leads us to distinguish the kinds of initiatives that are most likely to foster further development in particular areas depending upon the ways and degrees to which these areas have already developed. These distinctions in turn affect judgments with respect to the social responsibilities of international businesses operating in these areas. Thus, for example, the possibilities for economic development among the indigenous peoples of Guyana are quite different than those for Ghanaians in Ghana. The native Guyanese live by hunting, gathering, and rudimentary agriculture. The Ghanaians in contrast, have experience with extensively developed agriculture, 
local commerce, major cooperative enterprises, and modest manufacturing. The next steps in aiding the development of the native Guyanese economy, in so far as these people indicate their interest in these developments, are likely to involve something like enlarging primary educational opportunities, the development of local agricultural cooperatives, the modest expansion of infrastructures that protect these peoples and their lands from exploitation, and limited trade (see Whiteman 2004). In contrast, the situation in Ghana calls for quite different initiatives involving the extension and improvement of existing physical, social, and economic infrastructures, efforts to expand local manufacturing, and protection and enhancement of agriculture (see Puplampu 2004).

3. The current discussions with respect to appropriate technology transfers reflect this same kind of historical perspective. Developing countries are more likely to utilize effectively new technologies that correspond to their relative level of development. The least developed countries are more likely to take advantage of technologies that improve their agricultural production, aid in accessing and protecting water resources, and improve educational opportunities than, for example, in advanced manufacturing technologies. To be sure, the less developed areas can often benefit from some of the more recently developed technologies, including especially cell phones and internet access. These technologies can be utilized advantageously by people in very underdeveloped areas (see Prahalad 2005). The key factor in all instances is an historically informed sensitivity to current contingencies and possibilities.

4. Many essays on development seem to ignore the ways particular historical factors sets limits on what can and cannot be accomplished. They write about economic development in general terms - invoking the importance of markets, policy incentives, freedom in general - as if all undeveloped areas were at in similar situations, which they are not. What is possible in the present and near future in any particular area is shaped to a considerable degree by its current stage of development.

\section{Adopting an Historical Perspective for Monitoring Current Practices}

The practice of ethics not only calls for us to act in keeping with moral expectations. It also calls for us to monitor our actions in light of these expectations. Often this monitoring is done by gauging the degree to which current actions comply with these standards. In contrast, an historically informed practice of monitoring operates somewhat differently. It begins with the recognition that individuals, organizations, and circumstances are likely to undergo changes in a number of ways. If monitoring only takes places occasionally after significant stretches of time, then discrepancies between the overt profession of moral expectations and actual practices may increase without any clear sense of how and why these changes have occurred. In contrast, if we begin with the recognition that changes are likely to take place, then, correspondingly, we need to find ways of integrating the practice of monitoring into our on-going activities. Monitoring is not then primarily a way for others to check up on us. Rather, it is embodied as an on-going feature of how we review current situations in order to determine how 
to act. Instead of being a way of testing and policing after the fact, monitoring becomes integrated at the outset into the process of deciding how to act. It is viewed more as a way of fostering learning and less as an act of surveillance.

As we adopt an historically informed perspective on monitoring, we also learn to expect that unanticipated and sometimes adverse outcomes may well accompany well-intentioned initiatives. These occur frequently. Let me cite an example. In hopes of reducing poverty, in the early nineties The Body Shop decided to contract with an Amazonian village to produce Brazil nut oil, which it would buy and use in its retail products. This well-meaning project occasioned a number of unexpected problems. The community produced more nut oil than the Body Shop needed; the project aggravated rivalries with those villagers not included; and many workers used their augmented earnings immediately to consume products that aggravated their own health. Eventually, The Body Shop recognized the situation and re-organized their project to reduce these problems (see Bird 2004). Other examples of unanticipated adverse outcomes from ethical initiatives can be cited. In order to compensate for past discrimination, firms have taken initiative to hire and promote more minority group members. However, in many settings individuals who have benefited from these actions have had mixed reactions, especially where they are called upon too frequently to function like official representatives of these minority groups, where they feel exposed to excessive attention and expectations, and where they feel they are being treated in patronizing ways (see Kanter 1977).

An historical perspective does not really lead us to expect the completely unexpected. After all, a respect for history helps us to perceive patterns which can usefully inform and shape our expectations. However, this perspective reminds us that some discrepancy between moral commitment and action is a characteristic feature of moral actors for multiple reasons, such as the following:

- Conflicts and tensions between moral expectations. Calling, for example, both for greater output and more conservation, both for more freedom and greater equality; efforts both to enhance the situation of minorities and remain neutral with respect to difference;

- $\quad$ Setting excessively high moral expectations, at least for this moment in time;

- Genuine opposition or resistance from those who have alternative ethical priorities;

- Unsteady commitment from those with competing interests and commitments. A sense of history fosters an approach to ethics that fully recognizes that our best efforts may not succeed. And, therefore, we need to keep track of the outcomes of our efforts. A due regard for history occasions an orientation to moral action that is at once hopeful but fully aware of the possibility that things may go awry. This sense has variously been described as an appreciation of the "fragility of goodness," (see Nussbaum 1986), human fallibility (see Ricoeur 1986), and the tragic aspect of human life (see Niebuhr 1942). Optimism is thus chastened through historical reflections of the way the human capacity for greed, self-aggrandizement, and especially self-deception have frequently undermined well-meaning ethical projects (see Fingarette 1969). 
A due regard for history correspondingly shapes how we engage in ethical or social auditing in business enterprises. We are not primarily called upon to audit in order after the fact to expose non-compliance. That is a small part of the auditing process. Rather, we engage in auditing continuously in diverse ways in order to remain attentive and responsive to unfolding developments, in order to learn so that our judgments are wellinformed, and in order to foster and strengthen commitments by all those involved in our businesses and their operations. Auditing is primarily a forward-looking activity. We review in order to take stock so we can act more responsibly. Viewed from another perspective, we monitor not primarily to assign scores, grading firms in relation to one index or another. Rather, we monitor in order to provide and solicit useful feedback upon which we can act. Grades without feedback are not very instructive. We can engage in auditing through periodical evaluations, regular feedback sessions, and standardized surveys. Most importantly, we foster auditing by encouraging all relevant stakeholders to voice their concerns, not just negatively and irregularly as whistle blowers, but regularly in order to raise questions, bargain for their concerns, and take charge of issues overlooked by others. For example, all the employees at a chemical plant in Alberta were instructed with these words: "If you see a problem, then it's yours." Whether the perceived problem had to do with an oil slick on the road, a crisis at home, tensions between employees, or new way of running a chemical process, employees were empowered to take charge as they saw fit. On many occasions, taking charge meant calling attention to overlooked concerns (see Bird 1996; 2006; Patton 1997).

\section{Conclusion: A Due Regard for History Fosters a Strategic Perspective with Respect to the Practice of Ethics}

I have argued in this essay that a due regard for history affects the practice of ethics in a number of ways. It fosters a greater respect for historical conventions. It leads us to recognize the historical roots of contemporary ethical issues and challenges us to find fitting ways of dealing with not easily resolvable legacy issues. It cultivates an educated sense of contemporary contingencies, of what is and is not possible in given historical circumstances. It encourages us to learn from the past. Finally, a due regard for history invites us to regard ethical auditing not as an after the fact policing activity but as a continuous, forward-looking way of learning in face of ever changing conditions. Without a due regard for history, the practice of ethics has often become static, inattentive, and unresponsive to contemporary contingencies. While championing particular codes and standards, the ahistorical practice of ethics has often led people to overlook important moral issues not directly configured in the standards its proponents have adopted.

Nonetheless, inevitably, an ahistorical approach to ethics must take history seriously for two reasons. One, even as they affirm the validity of what they regard as universally valid standards, proponents of these standards must find ways of applying these standards with respect to historically formed and changing circumstances. Like Habermas (1993) they may argue that this application is appropriately called pragmatics while the identification and justification of these standards in turn properly constitutes ethics as such. However, this seems to be a scholastic distinction. As a human activity the practice of ethics involves exercising judgments about particular alternatives, issues, and dilemmas. It may well be that it is useful to invoke universally valid standards with respect, 
for example, to justice, human rights, human capabilities, and/or the common good. Nonetheless, in order to determine how to act in particular settings, we need to explore the bearing, weightiness, and utility of these and other normative standards as points of reference for helping us to address the exigencies of the historical settings we face. We cannot simply apply these standards without considering the ways and degrees they can be usefully invoked to help us judge how to act in the present. Two, statements of supposedly universally valid moral principles, such as, for example, Kant's categorical imperatives, the Universal Declaration of Human Rights, and the Hippocratic Oath to do no harm, are themselves products of history. They have gained authority not just because of the virtue of their articulation - their logic, claimed truthfulness, and moral compellingness - but also because increasingly large numbers of people over time have cited them to justify their own ethical decisions. They have become dominant ethical paradigms. Expressions of moral principles are cultural phenomena, emerging and gaining more or less authority over time.

The historically informed practice of business ethics by its very nature is a strategic activity. Whenever people attempt to make an ethical decision, they inevitably face a set of distinct but inter-related ethical questions. Each of these questions is important but different from the others. Sometimes people conflate these or overlook some of these questions and thus evade vital moral considerations. Typically, people rank order these questions. They assign greater importance to particular questions and address other questions from the perspective of the answers they have provided for the questions they regarded as preeminent. These fundamental ethical questions are as follows:

- What is the moral good I am seeking to realize in relation to the issue under consideration? What is the projected outcome of my actions? And how will this outcome further the good I am pursuing? The focus of this question is on the outcomes of action.

- What ways of acting are right or wrong? Which actions are correspondingly obligatory, prohibited, recommended, and/or highly acclaimed? The focus here is on the actions themselves and not on their motivations nor on their outcomes.

- How can we act in ways that are morally worthy? The focus here is on intentions as well as actions. The focus is on acting as morally worthy persons.

- In terms of current social conventions, what kind of action is expected? How do local traditions and customs shape moral expectations? The focus here is on cultural mores.

- Given current exigencies, what can we realistically expect to accomplish? How do we manage those likely to resist or oppose what we hope to do? The focus here shifts to the practical: that is to pragmatic considerations and political possibilities.

In practice, as we consider particular issues at specific points in time, we are faced with the task of assessing the relative importance of these diverse questions, determining our own priorities, finding fitting answers to these questions, and organizing our resources and commitments to act effectively. In the process, we are challenged to consider and balance various claims, to exercise judgment, to offer good reasons for our decisions, 
and persuade others to support our position. Thus, whether we acknowledge this fact or not, as we make up our minds about ethical issues we are engaged in a strategic activity, seeking, at this moment in time in relation to these issues, to balance and assign priority among these several implicit moral questions.

In particular, as an historically informed activity, the practice of business ethics is closely intertwined with the practices of business strategy. Conceived of in these terms, business ethics is not something extra and optional that businesses and managers can take up if they choose, like social philanthropy, for example, or an interest in design. As we engage in the practice of ethics, we are called correspondingly to review and learn from past experiences, analyze contemporary contingencies, and monitor current operations not only in relation to legal strictures, professional codes, and moral standards but also in relation to the way we utilize our assets and the good we can potentially realize. Ethical considerations arise in relation to most of the strategic decisions businesses make. They are central, for example, to how businesses manage their relations with their stakeholders (questions of reciprocity, honest and just negotiations, etc.) and exercise corporate governance (questions of fiduciary responsibility, accountability, due deliberation, etc.), how they view their best interests (minimizing costs or enhancing and protecting their assets) and how they allocate scarce organizational resources (questions of justice and human rights).

The practice of ethics and the practice of strategy are time-bound activities. As we develop strategies, we are called upon to determine what should be done when. Which actions have priority? What contingencies have to be taken into account? How are past actions and present commitments likely to shape the prospects for current endeavors? What are the most effective ways of realizing our objectives at this moment in time? How can we best utilize our resources under current circumstances in order to occasion desired outcomes?

To approach ethical decision-making historically, and hence strategically, is not to become a relativist. The standards we invoke to determine the good objectives we are seeking to realize and the right and wrong behaviors which should be followed and avoided remain weighty and compelling. Nonetheless, as we render judgments in relation to unfolding historical developments, these standards need to be balanced against each other. Moreover, historical contingencies will affect how we think about the good we seek to realize. Even as we assign ethical prominence to the good ends we seek to realize and standards of right conduct which serve as essential guides for how people ought to act, we need also to cultivate and respect relevant intentions and dispositions in order to motivate people to act in timely ways. Finally, in order to communicate and act effectively, we must additionally take account of relevant local conventions and pragmatic possibilities. If we take seriously our historical circumstances, then as we exercise judgment we must inevitably give due consideration to questions regarding moral worth, moral conventions, and practical possibilities. In the process these considerations are likely to shape and color our eventual judgments even when we pay highest respect to what we may well regard as universally valid goods - like the enhancement of human capabilities - and universally valid norms - like treating humans always as ends and never as means. 


\section{References}

Akabayashi, H./Psacharopoulos, G. (1999): The Trade-off Between Child Labour and Human Capital Formation: A Tanzanian case study, in: Journal of Development Studies, Vol. 35/No. 5, 120-140.

Basu, K. (1999): Child Labor: Causes, Consequences, and Cure: With Remarks on International Labor Standards, in: Journal of Economic Literature, Vol. 37/No. 3, 1083-1119.

Bessell, S. (1999): The Politics of Child Labor in Indonesia: Global Trends and Domestic Policy, in: Pacific Affairs, Vol. 72/No. 3, 353-371.

Bird, F. (1996): The Muted Conscience: Moral Silence and the Practice of Ethics in Business, Westport (CT): Quorum Books.

Bird, F. (2004): International Trade as a Vehicle for Reducing Poverty: The Body Shop's Community Trade Programme, in: Bird, F./Herman, S. (Eds.): International Businesses and the Challenges of Poverty in the Developing World, Houndmills, UK: Palgrave Macmillan.

Bird, F. (2006): Fostering Social Responsibility in Business: The Role of Ethical Auditing, in: Bird, F./Velasquez, M. (Eds.): Just Business Practices in a Diverse and Developing World, Houndmills, UK: Palgrave Macmillan.

Bird, F./Herman, S. (Eds.) (2004): International Businesses and the Challenges of Poverty in the Developing World, Houndmills, UK: Palgrave Macmillan.

Bird, F./Raufflet, E./Smucker, J. (Eds.) (2005): International Business and the Dilemmas of Development, Houndmills, UK: Palgrave Macmillan.

Bird, F./Smucker, J. (Eds.) (2007): The Social Responsibility of International Businesses in Developing Areas, in: Journal of Business Ethics, Special Issue, Vol. 73/No. 1.

Bird, F./ Velasquez, M. (Eds.) (2006): Just Business Practices in a Diverse and Developing World, Houndmills, UK: Palgrave Macmillan.

Bird, F./Waters, J. A. (1987): The Nature of Managerial Moral Standards, in: Journal of Business Ethics, Vol. 6/No. 1, 373-384.

Bird, F./Westley, F./Waters, J. A. (1990): The Uses of Moral Talk: Why Do Managers Talk Ethics?, in: Journal of Business Ethics, Vol. 8/No. 1, 75-89.

Brody, H. (2000): The Other Side Of Eden: Hunters, Farmers, and the Shaping of the World, Vancouver, Toronto: Douglas and McIntyre.

Business \& Human Rights Resource Centre (2016): Texaco/Chevron Lawsuits (re Ecuador), Link: business-humanrights.org/en/texacochevron-lawsuits-re-ecuador, last accessed 03/05/2016.

Chang, H.-J. (2007): Bad Samaritans: Rich Nations, Poor Policies, and the Threat to the Developing World, London: Random House.

Durkeheim, E. (1974/1925): The Determination of Moral Facts, Sociology and Philosophy, translated by D. F. Pocock, New York: The Free Press.

Dutton J./ Duncan, R. B. (1987): The Creation of Momentum for Change through the Process of Strategic Issues Diagnosis, in: Strategic Management Journal Vol. 8/No. 3, 279-295.

Dutton, J./Ottensmeyer, E. (1987): Strategic Issues Systems: Form, Function, Contexts, in: Academy of Management Review, Vol. 12/No. 2, 355-365.

Easterly, W. (2006): White Man's Burden: Why the West's Efforts to Aid the Rest Have Done So Much Ill and So Little Good, New York: Penguin Press.

Fingarette, H. (1969): Self-Deception, London: Routledge and Kegan Paul. 
Habermas, J. (1984/1981): Theory of Communicative Action, Vol. 1, translated by Thomas McCarthy, Boston: Beacon Press.

Habermas, J. (1993): Justification and Application: Notes on Discourse Ethics, translated by C. P. Cronin, Cambridge (Mass.): The MIT Press.

Hexham, I. (1981): The Irony of Apartheid: The Struggle for National Independence of Afrikaner Calvinism against British Imperialism, New York, Toronto: Edward Mellen Press.

Hofstede, G. (1980): Culture's Consequence: International Differences in Work-Related Values, Beverly Hills (CA): Sage.

Hofstede, G. (1991): Cultures and Organizations, London: McGraw Hill.

Hutchinson, S. E. (1996): Nuer Dilemmas: Coping with Money, War, and the State, Berkeley: University of California Press.

Jackall, R. (1988): Moral Mazes: The World of Corporate Managers, New York: Oxford University Press.

Jonsen, A. R./Toulmin, S. (1988): The Abuse of Casuistry: A History of Moral Reasoning, Berkeley: University of California Press.

Kanter, R. (1977): Men and Women of the Corporation, New York: Basic Books.

Khan, F. R. (2007): Representational Approaches Matter, in: Journal of Business Ethics, Vol. 73/No. 1, 77-89.

Klitgaard, R. (1990): Tropical Gangsters, New York: Basic Books.

Kluckholm, F./Strodbeck, F. L. (1961): Variations in Value Orientations, Westport (CT): Greenwood Press.

Machiavelli, N. (1950/1531): The Discourses, New York: Modern Library.

Machiavelli, N. (1950/1532): The Prince, New York: Modern Library.

Marx, K. (1961/1851): The Eighteenth Brumaire of Louis Bonaparte, New York: International Publishers.

Marx, K. (1973/1939): Grundrisse: Foundations of the Critique of Political Economy, Rough Draft, translated by Martin Nicolaus, London: Allen Lane.

Marx, K./Engels, F. (1947/1932): The German Ideology, Parts I and III, New York: International Publishers.

McIntyre, A. (1981): After Virtue, Notre Dame: University of Notre Dame Press.

McIntyre, A. (1988): Whose Justice? Which Rationality?, Notre Dame: University of Notre Dame Press.

Le Menestrel, M./Hunter, M./ de Bettignies, H.-C. (2002): Internet e-Ethics in Confrontation with an Activist's Agenda: Yahoo on Trial, in: Journal of Business Ethics Vol. 39/No.7, 135-144.

Milanovic, B. (2005): World's Apart: Measuring International and Global Inequality, Princeton: Princeton University Press.

Moebling, C. M. (1999): State Child Labor Laws and the Decline of Child Labor, in: Explorations in Economic History, Vol. 36/No. 1, 72-106.

Niebubr, H. R. (1963): The Responsible Self Cambridge: Cambridge University Press.

Niebubr, R. (1942): The Nature and Destiny of Man, New York: Charles Scribners.

Nussbaum, M. (1986): The Fragility of Goodness: Luck and Ethics in Greek Tragedies and Philosophy, Cambridge: Cambridge University Press.

Patton, M. (1997): Utilization Focused Evaluation, Thousand Oaks (CA): Sage. 
Puplampu, B. (2004): Capacity Building, Asset Development, and Corporate Values: A Study of Three International Firms in Ghana, in: Bird, F./Herman, S. (Eds.): International Businesses and the Challenges of Poverty in the Developing World, Houndmills, UK: Palgrave Macmillan.

Rawls, J. (1970): A Theory of Justice, Cambridge (Mass.): Harvard University Press.

Ricoeur, P. (1986): Fallible Man, translated by Charles Kelby, New York: Fordham University Press.

Rokeach, M. (1979): Understanding Human Values: Individual and Societal, New York: The Free Press.

Rostow, W. W. (1960): The Stages of Economic Growth, Cambridge: Cambridge University Press.

Sachs, J. (2005): The End of Poverty: Economic Possibilities for Our Times, New York: Penguin Press.

Sagawa, S./Segal, E. (2000): Common Interest: Common Good: Creating Value Through Business and Social Sector Partnerships, Boston: Harvard Business School Press.

Santoro, M. (2000): Profits and Principles: Global Capitalism and Human Rights in China, Cornell University Press.

Sen, A. (1999): Development as Freedom, New York: Oxford University Press.

Smelser, N. (1959): Social Change in the Industrial Revolution, Chicago: The University of Chicago Press.

Smucker, J. (2006): Pursuing Corporate Social Responsibility in Changing Institutional Fields, in: Bird, F./Velasquez, M. (Eds.): Just Business Practices in a Diverse and Developing World, Houndmills, UK: Palgrave Macmillan.

Sumner, W. G. (1906): Folkways: A Study of the Sociological Importance of Usages, Manners, Customs, Mores and Morals, Boston: Ginn and Company.

Taylor, C. (2004): Modern Social Imaginaries, Durham, London: Duke University Press.

Thorton, J. L. (2008): Long Time Coming: The Prospects for Democracy in China, in: Foreign Affairs, Vol. 87/No. 1, 2-22.

Thucydides (1954): History of the Peloponnesian War, translated by Rex Warner, London: Penguin Books.

De Tocqueville, A. (1945/1840): Democracy in America, Vol. I and II, The Henry Reeve Text as revised by Francis Bowen, New York: Vintage Books.

Waters, J. A./Bird, F. (1987): The Moral Dimensions of Organizational Cultures, in: Journal of Business Ethics Vol. 6/No. 1, 15-22.

Waters, J. A./Bird, F./Chant, P. (1986): Everyday Moral Issues Experienced by Managers, in: Journal of Business Ethics Vol. 5/No. 5, 373-384.

Weber, M. (1946/1846-1920): From Max Weber: Essays in Sociology edited by H.H. Gerth, and C. W. Mills, New York: Oxford University Press.

Weber, M. (1949/1904): 'Objectivity' in the Social Sciences and Social Policy, The Methodology of the Social Sciences, translated and edited by E. A. Shils and H. A. Finch, New York: The Free Press, 50-112.

Whiteman, G. (2004): Forestry, Gold Mining and Amerindians: The Troubling Examples of Samling in Guyana, in Bird, F./Herman, S. (Eds.): International Businesses and the Challenge of Poverty in the Developing World, Houndmills, UK: Palgrave Macmillan. 